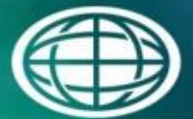

Savannah River

National Laboratory

OPERATED BY SAVANNAH RIVER NUCLEAR SOLUTIONS

A U.S. DEPARTMENT OF ENERGY NATIONAL LABORATORY • SAVANNAH RIVER SITE • AIKEN, SC

\title{
Analysis of a Global Database Containing Tritium in Precipitation
}

R. L. Buckley, R. L. Rabun III, and M. Heath

February 17, 2016

SRNL-STI-2016-00071 


\section{DISCLAIMER}

This work was prepared under an agreement with and funded by the U.S. Government. Neither the U.S. Government or its employees, nor any of its contractors, subcontractors or their employees, makes any express or implied:

1. warranty or assumes any legal liability for the accuracy, completeness, or for the use or results of such use of any information, product, or process disclosed; or

2. representation that such use or results of such use would not infringe privately owned rights; or

3. endorsement or recommendation of any specifically identified commercial product, process, or service.

Any views and opinions of authors expressed in this work do not necessarily state or reflect those of the United States Government, or its contractors, or subcontractors.

Printed in the United States of America

Prepared for

U.S. Department of Energy 
Keywords: Tritium, Precipitation, Data Evaluation

Retention: Permanent

\section{Analysis of a Global Database Containing Tritium in Precipitation}

R. L. Buckley, R. L. Rabun III, and M. Heath*

* Served as summer intern through

Savannah River Tritium Enterprise

February 17, 2016

under contract number DE-AC09-08SR22470. 


\section{REVIEWS AND APPROVALS}

AUTHORS:

R. L. Buckley, Atmospheric Technologies Group Date
R. L. Rabun III, Threat Assessments
Date

TECHNICAL REVIEW:

Brian J. Viner, Atmospheric Technologies Group Date

APPROVAL:

C. H. Hunter, Manager Date

Atmospheric Technologies Group 


\section{EXECUTIVE SUMMARY}

The International Atomic Energy Agency (IAEA) directed the collection of tritium in water samples from the mid-1950s to 2009. The Global Network of Isotopes in Precipitation (GNIP) data examined the airborne movement of isotope releases to the environment, with an objective of collecting spatial data on the isotope content of precipitation across the globe. The initial motivation was to monitor atmospheric thermonuclear test fallout through tritium, deuterium, and oxygen isotope concentrations, but after the 1970s the focus changed to being an observation network of stable hydrogen and oxygen isotope data for hydrologic studies. The GNIP database provides a wealth of tritium data collections over a long period of time. The work performed here primarily examined data features in the past 30 years (after much of the effects of above-ground nuclear testing in the late 1950s to early 1960s decayed away), revealing potentially unknown tritium sources. The available data at GNIP were reorganized to allow for evaluation of trends in the data both temporally and spatially. Several interesting cases were revealed, including relatively high measured concentrations in the Atlantic and Indian Oceans, Russia, Norway, as well as an increase in background concentration at a collector in South Korea after 2004. Recent data from stations in the southeastern United States nearest to the Savannah River Site do not indicate any high values. Meteorological impacts have not been considered in this study. Further research to assess the likely source location of interesting cases using transport simulations and/or literature searches is warranted. 


\section{TABLE OF CONTENTS}

LIST OF FIGURES Vii

I. INTRODUCTION

$\begin{array}{ll}\text { II. METHODOLOGY } & 1\end{array}$

A. Data Download

B. Data Examination $\quad 1$

1. Mapping Technique 1

2. Temporal Evaluation 2

3. Spatial Evaluation 2

III. RESULTS 2

A. Spatial Trends $\quad 2$

B. Temporal Trends 3

IV. CONCLUSIONS

$\begin{array}{lc}\text { REFERENCES } & 5\end{array}$ 


\section{LIST OF FIGURES}

Figure 1: Map of all GNIP stations.

Figure 2: Map of selected GNIP stations with high tritium concentration measurements (red circles), nuclear power plants (green diamonds), and nuclear test sites (blue triangles).

Figure 3: Time-series of GNIP tritium concentrations for all of the United States stations for (a) the entire period of record (on a semi-logarithmic scale), and (b) 1990 2009 (on a linear scale).

Figure 4: Plots of global variations in tritium concentration for a given month where yellow dots denote sample locations for that month. (a) March 2005, and (b) January 2006.

Figure 5: Time series of tritium concentrations for the Antarctica stations from 1990 to 2009.

Figure 6: Map of ocean-based GNIP stations near Africa (outlined) with high tritium concentrations of tritium in precipitation. The closest nuclear power station source is shown in yellow.

Figure 7: Time series of GNIP tritium concentrations at (a) Ascension Island (Atlantic Ocean) from 1990 to 2009, and (b) Marion Island (Indian Ocean) from 1984 to 2009.

Figure 8: Map of region with GNIP sample locations of unusually high tritium concentrations in Russia (St. Petersburg) and Norway (Ny Alesund). Nuclear power station sources are shown in yellow and a test site in Novaya Zemlya is indicated in blue.

Figure 9: Time series of GNIP tritium concentrations at St. Petersburg, Russia (and available data from other stations in the region) from 1980 to 1991.

Figure 10: Time series of GNIP tritium concentrations at Ny Alesund, Norway (and available data from other stations in the region) from 1990 to 2009.

Figure 11: Map of region with GNIP sample locations of unusually high tritium concentrations in South Korea (Cheongju). Nuclear power station sources are shown in yellow and a test site in North Korea is indicated in blue.

Figure 12: Time series of GNIP tritium concentrations at Cheongju, South Korea from 1998 to 2009

Figure 13: Map of southeastern United States with potential sources of tritium (nuclear power station in yellow, DOE Savannah River Site in blue) along with GNIP samplers (red). 
Figure 14: Annual tritium emissions (Ci) from the Savannah River Site.

Figure 15: Time-series of GNIP tritium concentrations at Ocala, Florida and Hatteras, North Carolina. (a) Annual average from 1961 to 2007. (b) Monthly average from 1980 to 2007. 


\section{INTRODUCTION}

The purpose of this research was to determine if data collected by the International Atomic Energy Agency (IAEA) for tritium in water samples from the mid-1950s to 2009 reveal potentially unknown sources of tritium. There were two forms of data collection: (1) GNIP (Global Network of Isotopes in Precipitation) that examined airborne movement of isotope releases to the environment, and (2) GNIR (Global Network of Isotopes in Rivers ${ }^{1}$ ), that examined aqueous migration through rivers, streams, estuaries, etc. Both sets of data have been stored in the WISER database (Water Isotope System for Data Analysis, Visualization and Electronic Retrieval $^{2}$ ) that is available for online download with acquisition of a user account. The focus and data collections used for this particular research was the GNIP data. The GNIP data collections became operational in 1961 with an objective of collecting spatial data on the isotope content of precipitation across the globe. The initial motivation was to monitor atmospheric thermonuclear test fallout through tritium, deuterium, and oxygen isotope concentrations, but after the 1970s the focus changed to being an observation network of stable hydrogen and oxygen isotope data for hydrologic studies. Extensive research examining this data has been published ${ }^{3-6}$.

\section{METHODOLOGY}

\section{A. Data Downloaded}

Over fifty years of data exists and was downloaded with a focus on the more recent data (1980 - 2009). The data are arranged by individual station, with dates of collection, sample concentration for the month for each of the isotopes, precipitation type and amount, as well as air temperature and partial pressure of water vapor provided on typically a monthly basis. The data are thoroughly analyzed by strict guidelines ${ }^{3,7}$ as determined by the IAEA in co-operation with the World Meteorological Organization (WMO). The WISER database is organized such that individual stations are stored in Microsoft Excel files for each station. Thus, individual timeseries of data for a given station are easily determined. However, the goal of this project was to organize the data such that multiple stations could be examined for both temporal and spatial trends. Data was downloaded for every station that contained at least one month of tritium data. This included over 600 monthly sampling stations. In addition, there were a number of "event" stations, in which collections were not made at regular monthly intervals, but rather intermittently (twice monthly, daily, etc.) The latter type of station data was not examined in depth here. The data are broken up into seven regions (Africa, Asia, South America, North/Central America, Southwest Pacific, Europe, and Antarctica). A map of all stations (with at least one month of reporting over the entire period of collection) is shown in Figure 1.

\section{B. Data Examination}

\section{Mapping Technique}

The locations (latitudes and longitudes) of the GNIP sampling stations were plotted on a map (Figure 1) using the software package ArcGIS ${ }^{9}$. Figure 2 is a plot of selected GNIP stations with high tritium concentrations at some time during their collection history, along with nuclear power stations currently in operation ${ }^{8}$, and a few selected nuclear test sites. This software tool allowed for the distance between sampling stations, power stations, and test sites to be measured, as 
well as provide a visual indication of geographic locations of sources and samplers. By being able to determine the distance between different locations, a clearer picture is illustrated of potential sources of tritium concentration variations. To place the stations on the map, an excel file was created with the station ID, latitude, and longitude. The excel file was then converted into a shape file (a readable format for ArcGIS) by using another related software package, ArcCatalog 9 .

\section{Temporal Evaluation}

More than fifty years of data was downloaded and charts were created using the GNIP time series. These charts allowed for a closer look at the long term trends in the overall data for entire regions. Since data prior to 1990 had been examined to some extent ${ }^{3}$, the focus of this research was on more recent data $(1980-2009)$. Charts were then created using this new time series. In addition to allowing trends to be analyzed, the new charts allowed for stations with abnormally high tritium concentrations in the past twenty years to be examined. By plotting the stations with high tritium concentration, the overall purpose of this research was realized. An example time-series for all U. S. stations is given in Figure 3a for the entirety of the data collection, revealing the effects of above ground nuclear testing in the late 1950's and early 1960's. The U.S. station data for the most recent 20 years is shown in Figure 3b, on a muchreduced concentration scale. The concentration values are expressed in tritium units (TU). Note that $1 \mathrm{TU}=3.237 \mathrm{pCi} / \mathrm{kg}$ of water ${ }^{10}$ and knowing the partial pressure of water vapor and temperature allows for a conversion to $\mathrm{pCi} / \mathrm{m}^{3}$ of air.

\section{Spatial Evaluation}

The data was further compiled into a spreadsheet containing the latitude, longitude, station ID, and tritium concentration. From these data, a shape file was created using ArcCatalog for each month. Spatial plots were then created using the spatial analyst tools in ArcGIS and the inverse distance weighted technique (IDW) to interpolate the tritium data. With IDW, cell values are estimated by averaging sample data values in the vicinity of the processing cells. Data points closer to a given cell are more strongly weighted ${ }^{9}$. These spatial plots, with a common scale, were created for every month from 1990-2009. The purpose for creating these spatial plots was to create a tool that highlighted the areas of interest (e.g., those in dark red that illustrate relatively high tritium concentration). An example of spatial variability of the tritium data is shown in Figure 4. The top panel for March 2005 indicates higher concentrations at a South Korean station than other stations, while the bottom panel for January 2006 indicates a similar situation for a Norwegian station located near the Arctic Circle. Viewing a series of these plots quickly provides variations in concentration such that "hot spots" may be easily identified.

\section{RESULTS}

\section{A. Spatial Trends}

The spatial trends were useful in establishing general background concentration levels. It is seen from examining the data from 1990 - 2009 that measurements exceeding $100 \mathrm{TU}$ is somewhat rare. Most of the data collections exceeding $>100 \mathrm{TU}$ are discussed in the next section. 
The variability (both temporally and spatially) in tritium concentration is due to a number of items, including seasonal changes in weather patterns, local geographical configuration, and the existence of tritium emission sources at varying distances from the sampler.

\section{B. Temporal Trends}

Several interesting features in the data were noted by creating the time-series plots by region. A clear seasonal variation in tritium was seen in Antarctica (Figure 5) with a maximum tending to occur between April and September. Cauquoin et al. ${ }^{6}$ attribute this pattern to dryer air masses and stronger stratospheric moisture influx during the southern hemisphere winter.

There were a number of other interesting trends in the data collections. The first involved two oceanic GNIP stations (Figure 6). Ascension Island is located in the Atlantic Ocean roughly $1500 \mathrm{~km}$ south-southwest of Liberia and $3000 \mathrm{~km}$ west of Angola and Marion Island is located in the Indian Ocean roughly $2000 \mathrm{~km}$ southeast of South Africa. The nearest land-based nuclear facility is located near Cape Town, South Africa. Time series of monthly tritium collections is shown in Figure 7 for both of these island locations. It is clear that a number of sustained periods with elevated tritium concentration have been collected. For Ascension Island, these elevations occurred in the early and mid-1990s, while for Marion Island, a number of elevated concentrations were observed in 2009. Recent research ${ }^{11}$ indicates a link between earthquake activity and increases in tritium in water from rain, springs, wells, rivers, and lakes. An investigation of earthquake activity in the mid-1990s near Ascension Island, and the late 2000s near Marion Island would be helpful.

Another interesting period with elevated concentrations occurred at St. Petersburg, Russia (a map of the region is shown in Figure 8) in mid-1990 (Figure 9). There have been several incidents reported at the Leningrad Nuclear Power Plant (between 1974 and 2015) ${ }^{12}$ roughly $140 \mathrm{~km}$ to the west of the St. Petersburg sampler. Unfortunately, there were no further GNIP collections at St. Petersburg after September 1990. Note that the tritium concentrations here are a factor of 10 to 100 above the global baseline.

A Norwegian station exists at Ny Alesund, north of the European mainland (Figure 8). It is more than $1000 \mathrm{~km}$ from any fixed tritium source. The time-series shown in Figure 10 indicates sustained elevations in tritium concentrations in both 2006 and 2009 . The peak values in both instances occur during the summer months. Prior research indicates this could be due to discontinuities of the tropopause at mid-latitudes and the exchange of tropospheric and stratospheric air masses in baroclinic zones ${ }^{13}$. However, the elevated values in 2006 occurred for almost an entire year. Smaller elevations above background during the warmer months are also observed in the mid-1990s.

A station in Cheongju, South Korea (Figure 11) revealed a change in background concentration. The map indicates a number of possible tritium sources in South Korea, although releases from North Korea should not be ruled out. Known South Korea power stations are all at least 200 km distant from the sample location. The time-series shown in Figure 12 is interesting in that measured concentrations prior to 2005 have a lower background (roughly 10 TU) than starting in 2005 (roughly 30 TU). In fact, the two highest concentrations beginning in 2005 both occur in March. A decline over time (starting in January 2005) of the background concentration at Cheongju, South Korea may be seen in the data as well. The South Korean heavy water detritiation facility at Wolsong began operations in the early 2000s, and could be a factor in the step change in the Korean data. 
Finally, the measurements for the two stations closest to the Savannah River Site (SRS) in the southeastern United States were also examined. A map of the region is shown in Figure 13. Although there are a number of nuclear power stations in the vicinity, the SRS has historically produced tritium for defense-related purposes and has a recorded emission history. The nearest GNIP stations are at Ocala, Florida (530 km to the south) and at Hatteras, North Carolina (730 km to the northeast). Data depicting SRS tritium emissions ${ }^{14}$ is shown in Figure 14. There is clearly a downward trend in emissions over time after peaking in the late 1950s. The GNIP data for the Ocala and Hatteras stations is indicated in Figure 15, where the entire date range as averaged annually is shown in panel (a), while a more recent period of monthly averages (1980-2009) is given in panel (b). The long-term data indicate weapons testing fallout, with possible contribution from the SRS. For the more recent data, there were slight elevations at Hatteras, NC (July and August 1983, as well as June 1988) with potential contribution from some inadvertent releases at SRS ${ }^{15}$. Further research would need to be done to determine if the SRS releases contributed to the elevations in North Carolina. The most recent data (1990 onward) shows low concentrations relative to early time periods.

\section{CONCLUSIONS}

The GNIP database provides a wealth of tritium data collections over a long period of time (roughly 50 years). Although the GNIP data are subject to standard protocols as set by the IAEA, future studies could involve examination of the lab QA/QC data to ensure that shifts or spikes seen in the data are real. The work performed here primarily examined data features in the most recent 30 years (after the effects of above-ground nuclear testing in the late 1950s to early 1960s have decayed away), revealing potentially unknown tritium sources. Meteorological factors were not considered in this work. Further research to assess the likely source location using transport simulations and/or literature searches is warranted. The available data at GNIP were reorganized to allow for evaluation of trends in the data both temporally and spatially. Several interesting cases were revealed, including unusually high measurements in the Atlantic and Indian Oceans, Russia, Norway, as well as an increase in background concentration at a collector in South Korea. Certainly, there are non-proliferation aspects to be considered in further analysis. Finally, recent data from nearby stations to the SRS do not indicate any elevated concentrations.

\section{ACKNOWLEDGEMENT}

The support of Savannah River Tritium Enterprise (SRTE) is acknowledged and appreciated. Morgan Heath performed this research in 2015 through a summer internship program sponsored by SRTE. 


\section{References}

1. http://www-naweb.iaea.org/napc/ih/lHS resources gnip.html, accessed 10 February, 2016.

2. http://www-naweb.iaea.org/napc/ih/lHS resources isohis.html, accessed 10 February, 2016.

3. International Atomic Energy Agency (IAEA), 1992: Statistical Treatment of Data on Environmental Isotopes in Precipitation. Technical Report Series No. 331, Vienna, Austria, $781 \mathrm{pp}$.

4. Van Der Wel, L.G.; Streurman, H.J.; Isaksson, E.; Helsen, M.M.; Van De Wal, R.S.W.; Martma, T.; Pohjola, V.A.; Moore, J.C.; Meijer, H.A.J., 2011: Using high-resolution tritium profiles to quantify the effects of melt on two Spitsbergen ice cores. Journal of Glaciology, 57 (206), 1087-1097.

5. Tadros, C. V.; Hughes, C. E.; Crawford, J.; Hollins, S. E.; Chisari, R., 2014: Tritium in Australian precipitation: A 50 year record. Journal of Hydrology, 513, 262-273.

6. Cauquoin, A.; Jean-Baptiste, P.; Risi, C.; Fourré, E.; Stenni, B.; Landais, A., 2015: The global distribution of natural tritium in precipitation simulated with an Atmospheric General Circulation Model and comparison with observations. Earth and Planetary Science Letters, 427, 160-170.

7. http://wwwnaweb.iaea.org/napc/ih/documents/other/GNIP\%20station\%20operation\%20manual Feb13 EN.pdf, accessed 10 February, 2016.

8. International Atomic Energy Agency (IAEA), 2015: Nuclear Power Reactors in the World, Reference Data Series No. 2, Vienna, ISBN 978-92-0-104915-5 ISSN 1011-2642, 86 pp.

9. ESRI, 2015: ArcGIS Desktop: Release 10. Redlands, CA: Environmental Systems Research Institute. See also http://resources.arcgis.com/en/home/, accessed 10 February, 2016.

10. Östlund, H. G. and A. S. Mason, 1985: Atmospheric Tritium 1968 - 1984. Tritium Laboratory Data Report No. 14, University of Miami, Rosenstiel School of Marine and Atmospheric Science, Final Report Contract DE-AS05-76EV03944, U.S. Department of Energy.

11. Tsvetkova, T., I. Nevinsky, V. Nevinsky, and B. Suiatin, 2014: Tritium measurement in the Western Caucasus. J. Radioanal. Nucl. Chem., 302, 1265-1269.

12. Ha-Duong, M. and V. Journe, 2014: Calculating nuclear accident probabilities from empirical frequencies. Environ. Syst. Decis., 34 (2), 249-258.

13. Newell, R. E., 1963: Transfer through the tropopause and within the stratosphere. Q. J. R. Meteorol. Soc. 89 (380), 167-204.

14. SRS Environmental Reports, 1955 to 2012.

15. Carlton, W. H., C. E. Murphy Jr., L. R. Bauer, D. W. Hayes, W. L. Marter, C. C. Zeigler, R. L. Nichols, R. N. Strom, B. R. del Carman, D. M. Hamby, D. D. Hoel, and D. E. Stephenson, 1993: Assessment of Tritium in the Savannah River Site Environment, Westinghouse Savannah River Company, Savannah River Technology Center, WSRC-TR-93-214. 


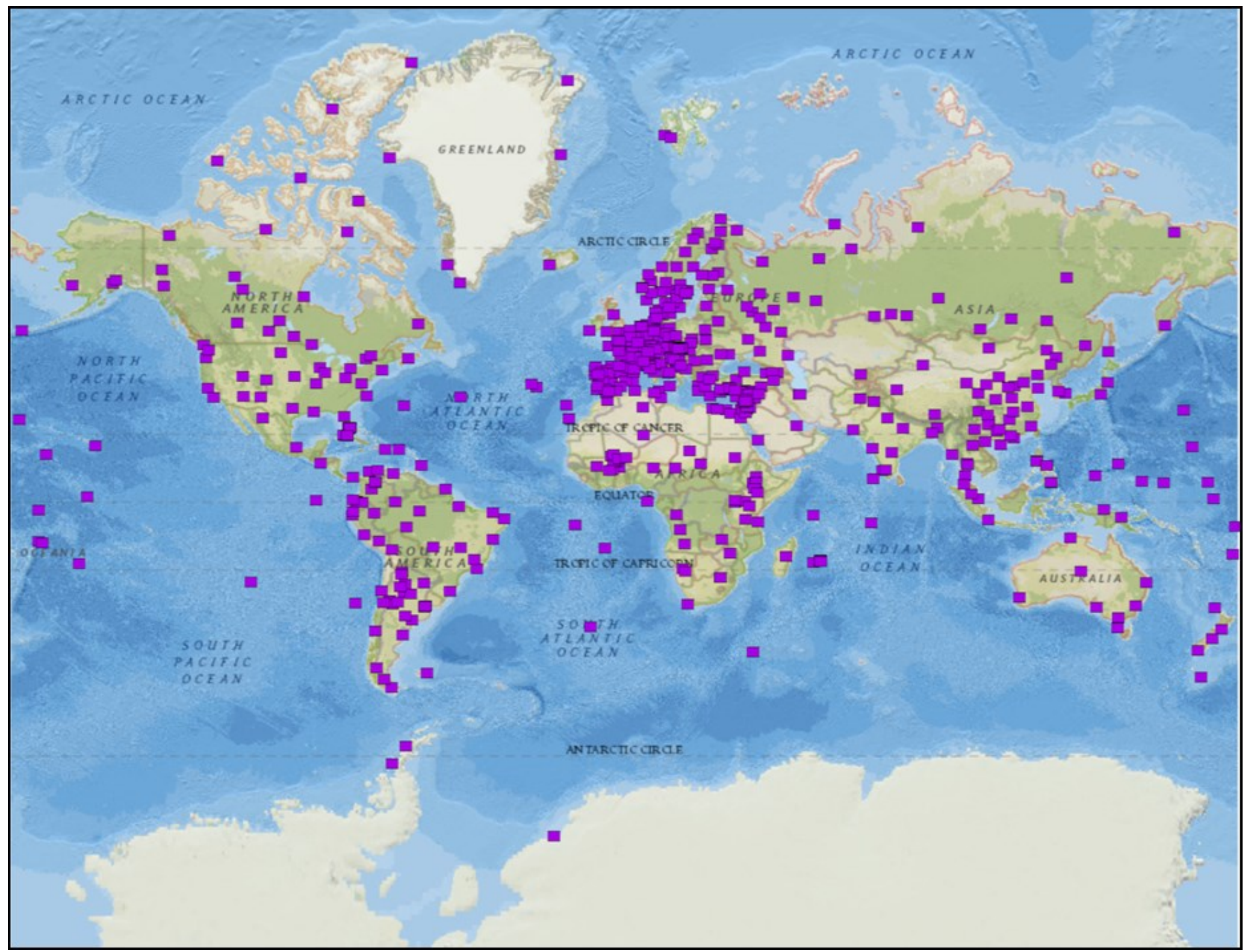

Figure 1: Map of all GNIP stations. 


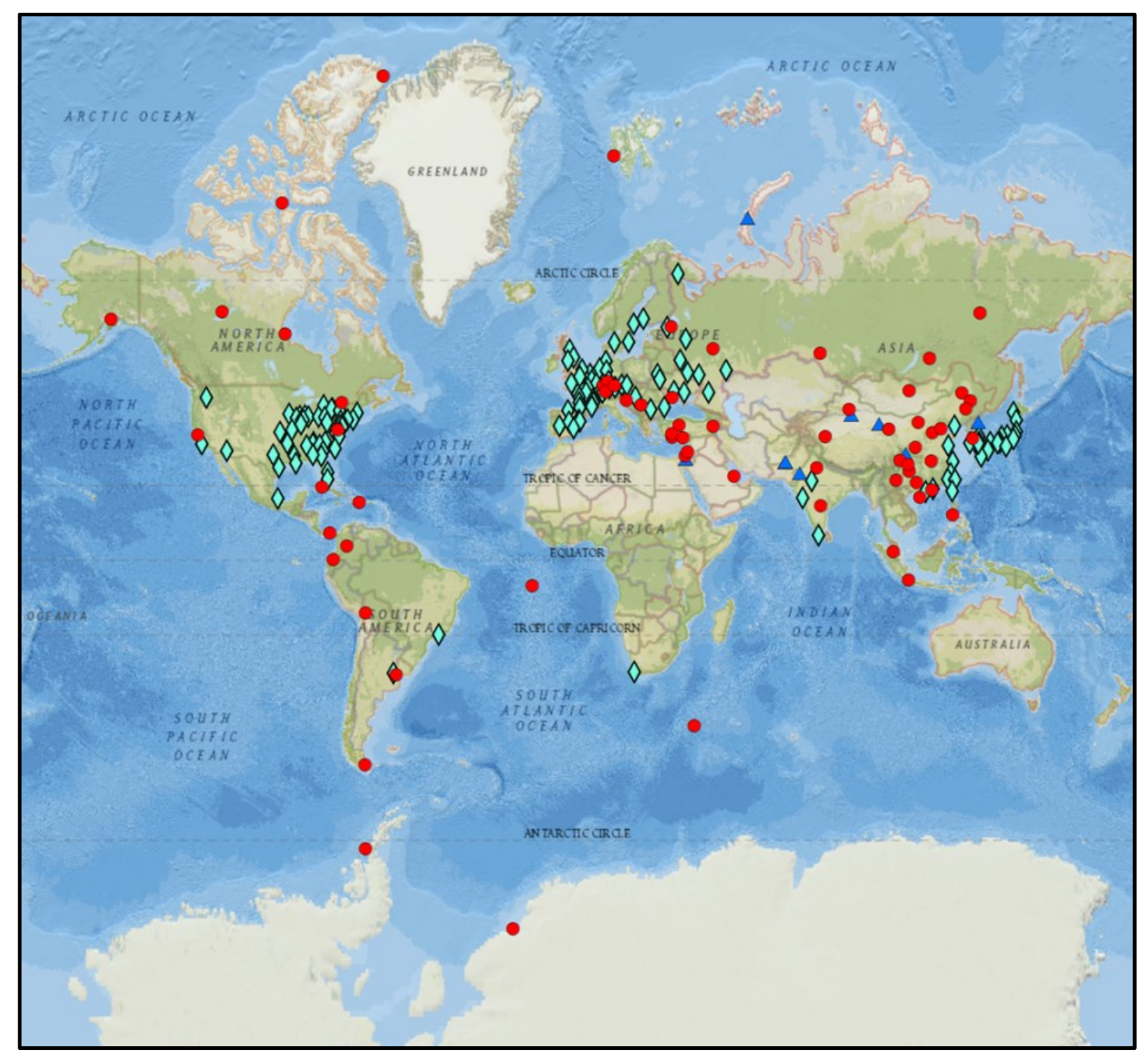

Figure 2: Map of selected GNIP stations with high tritium concentration measurements (red circles), nuclear power plants (green diamonds), and nuclear test sites (blue triangles). 
(a)

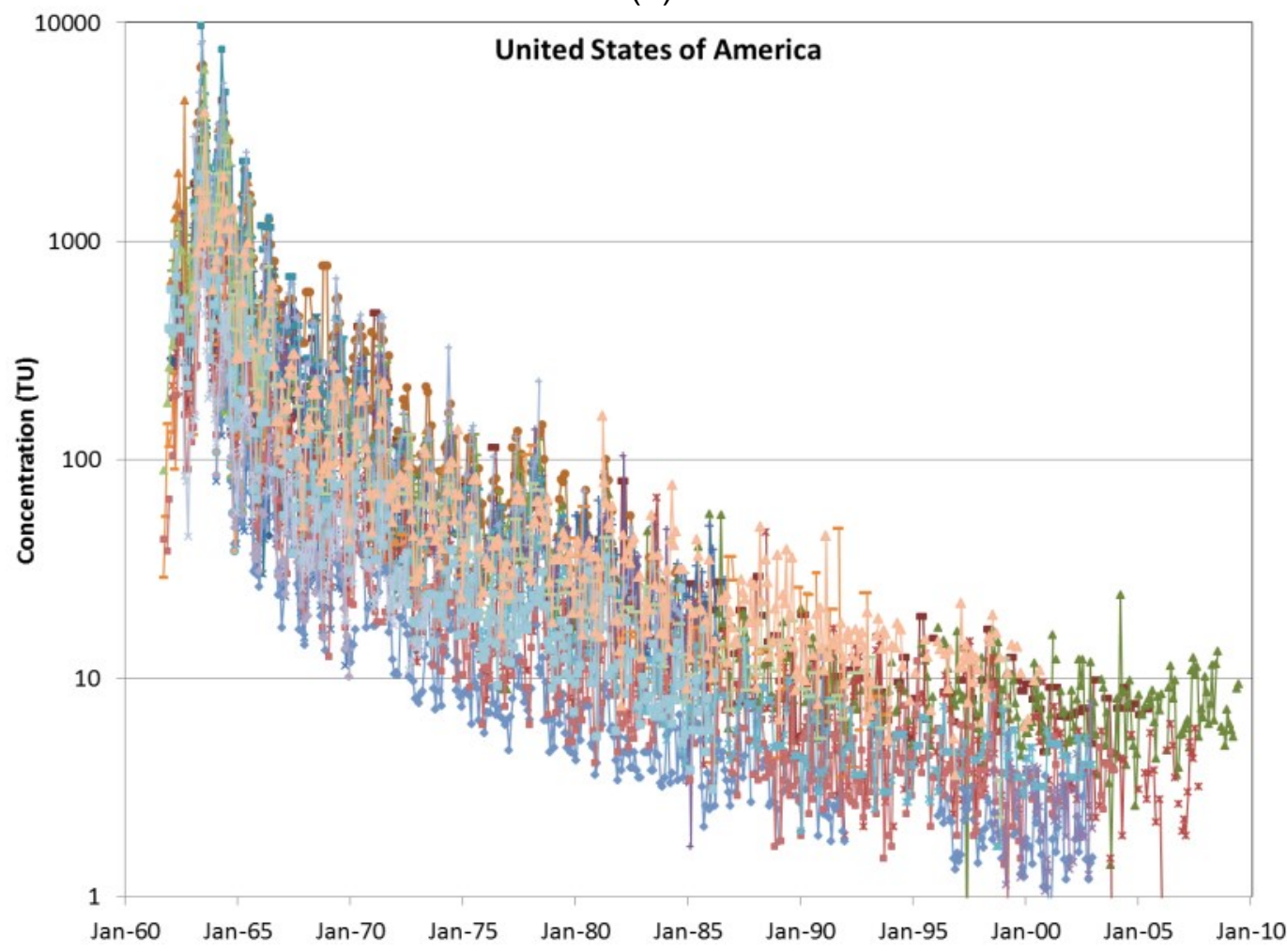

(b)

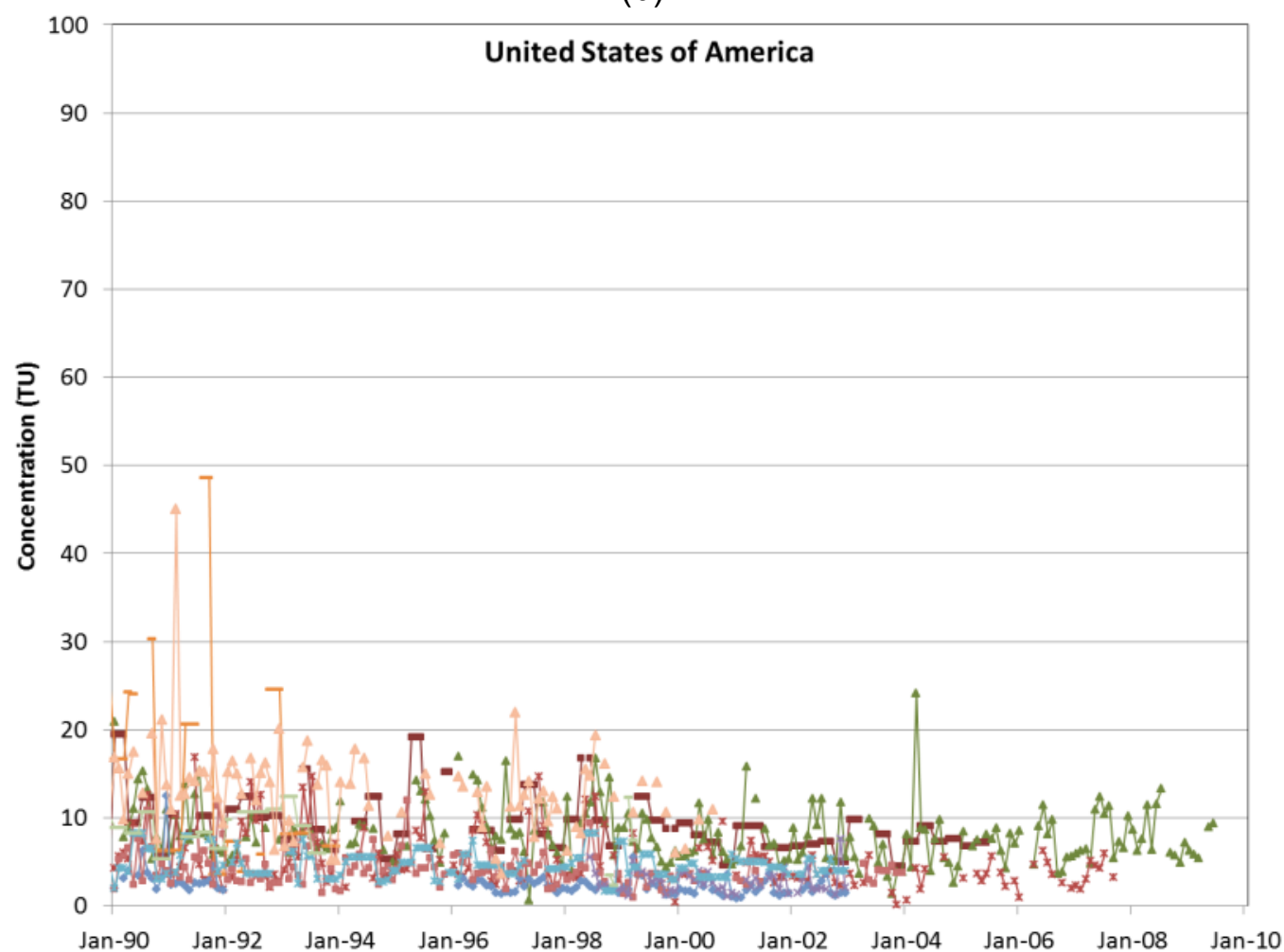

Figure 3: Time-series of GNIP tritium concentrations for all of the United States stations for (a) the entire period of record (on a semi-logarithmic scale), and (b) $1990-2009$ (on a linear scale). 
(a)

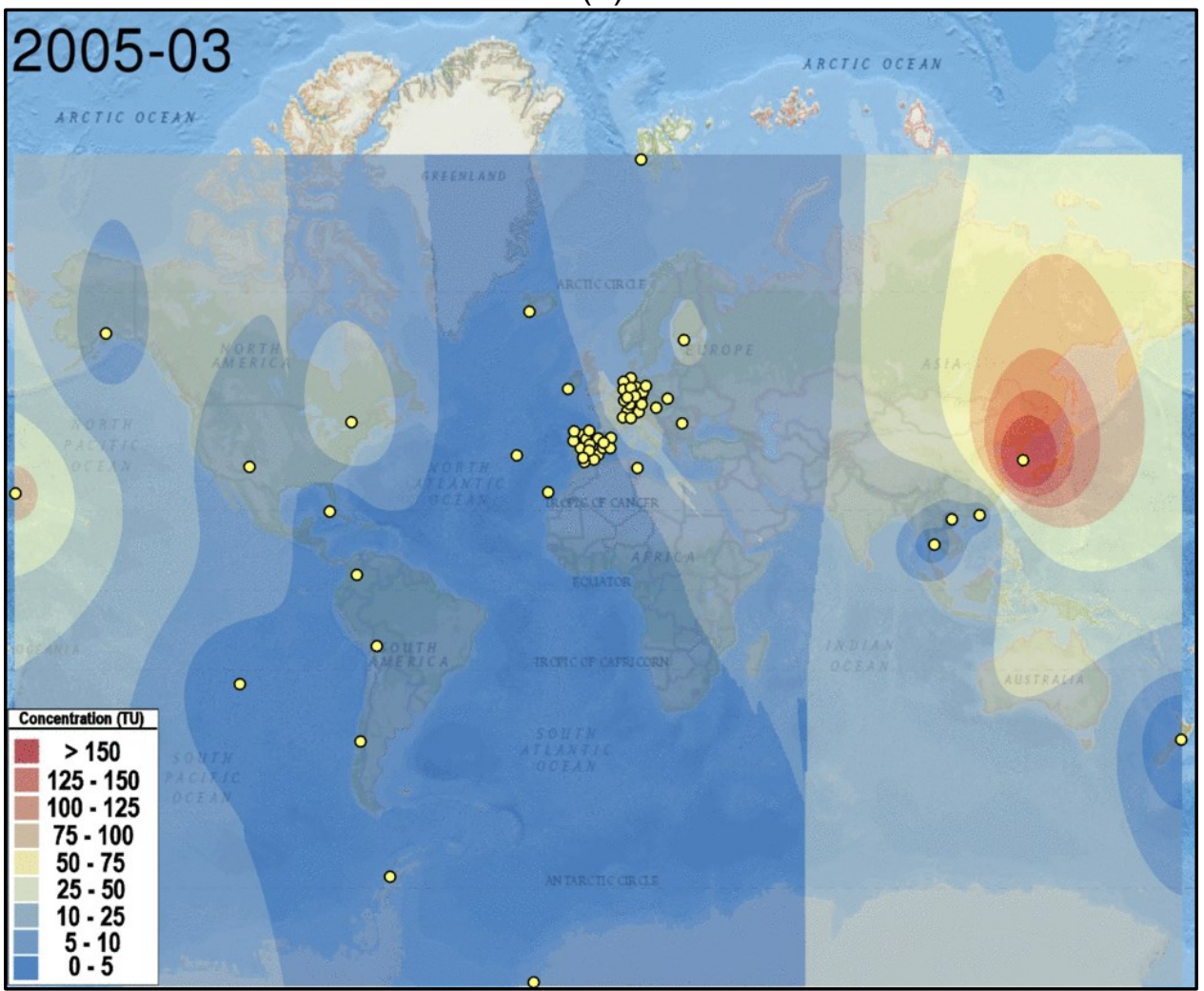

(b)

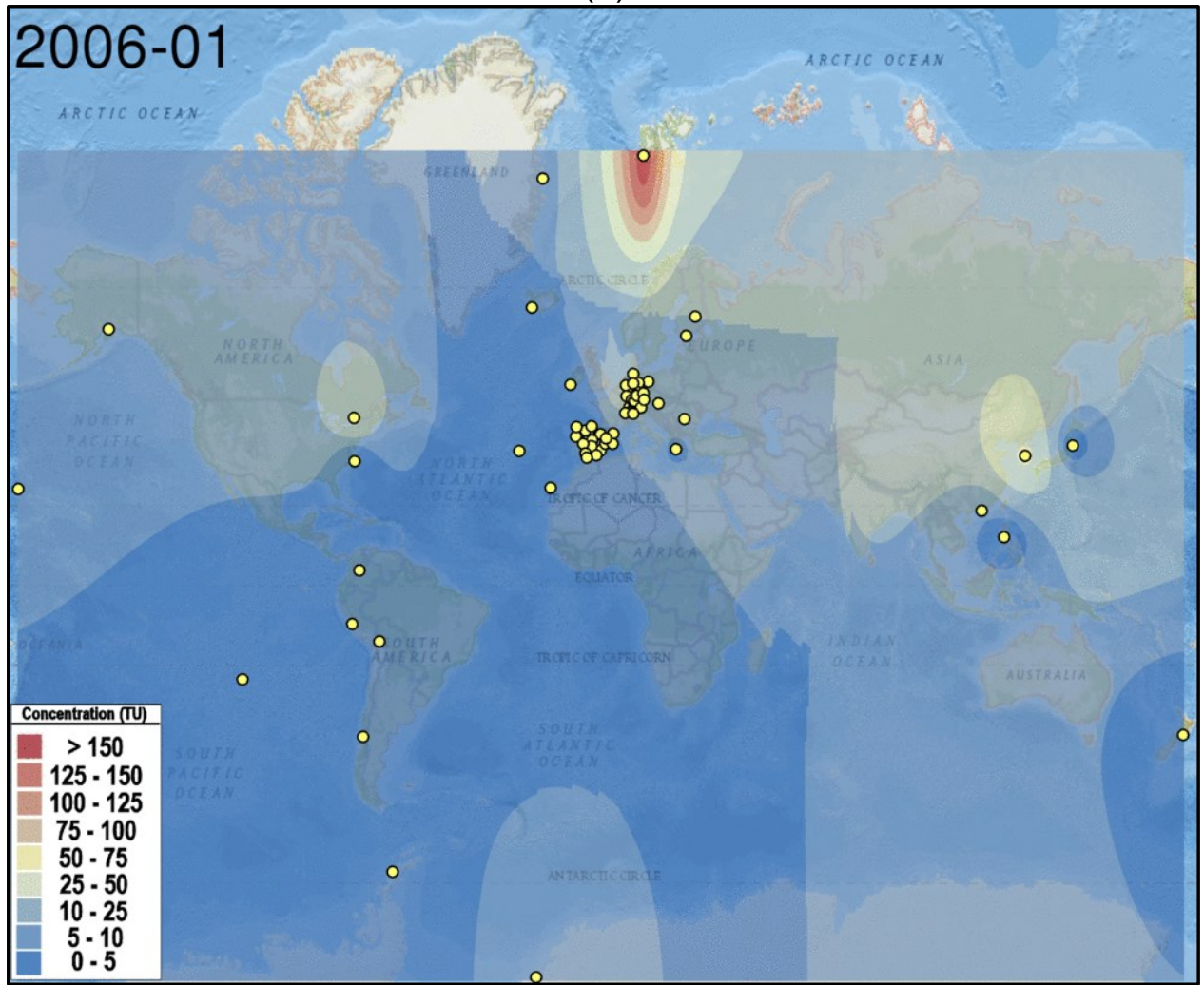

Figure 4: Plots of global variations in tritium concentration for a given month where yellow dots denote sample locations for that month. (a) March 2005, and (b) January 2006. 


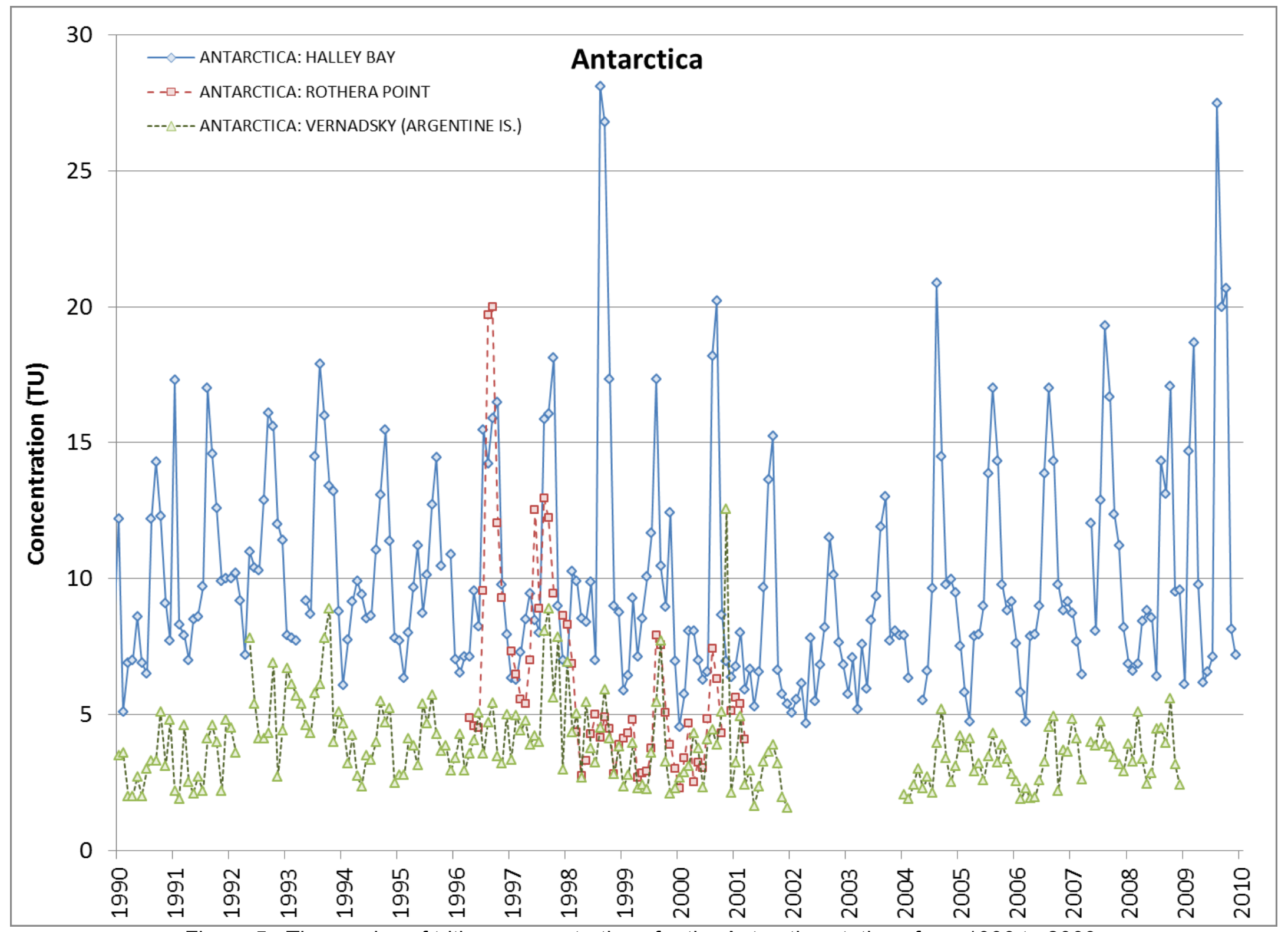

Figure 5: Time series of tritium concentrations for the Antarctica stations from 1990 to 2009. 


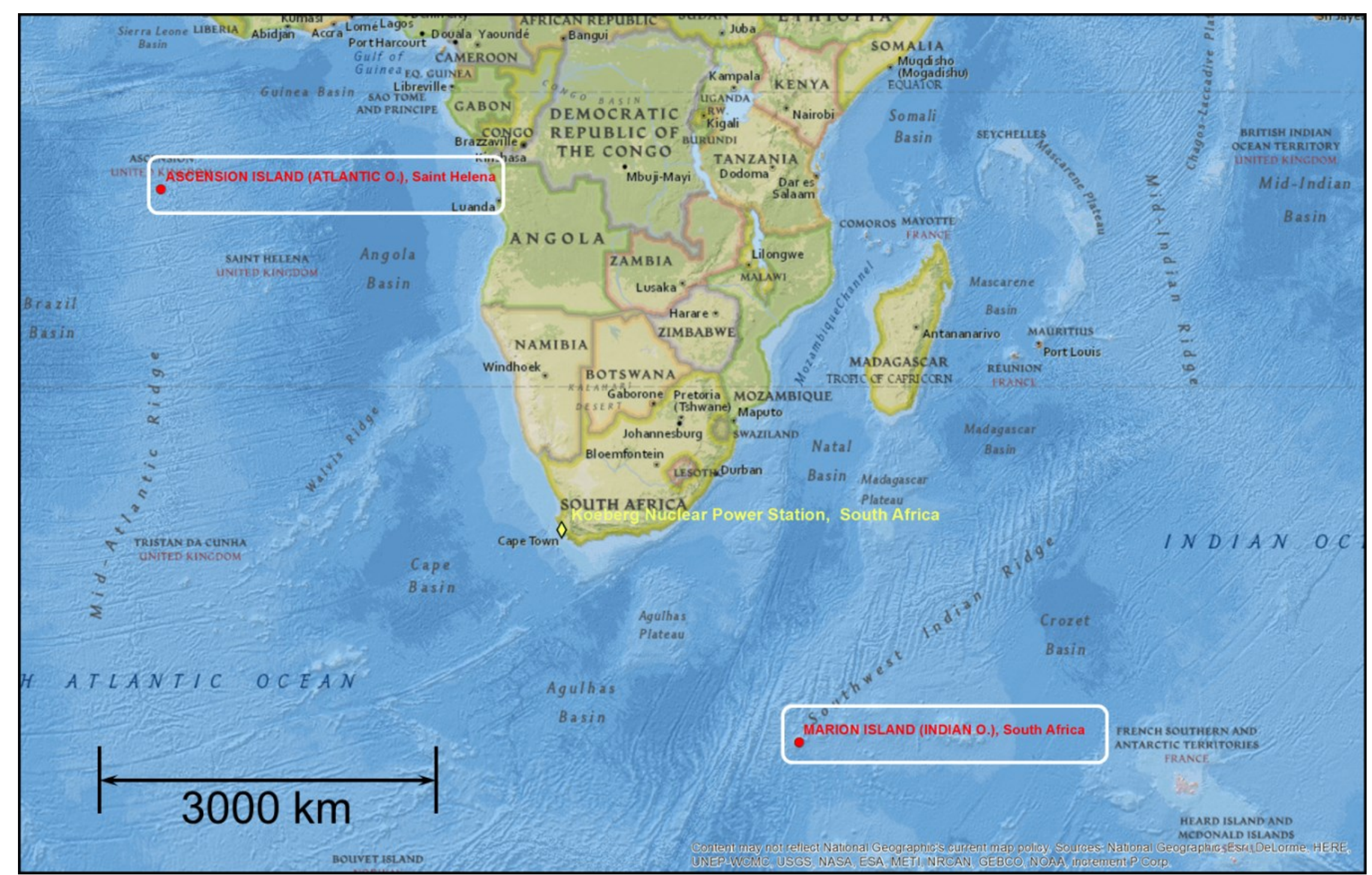

Figure 6: Map of ocean-based GNIP stations near Africa (outlined) with high concentrations of tritium in precipitation. The closest nuclear power station source is shown in yellow. 
(a)

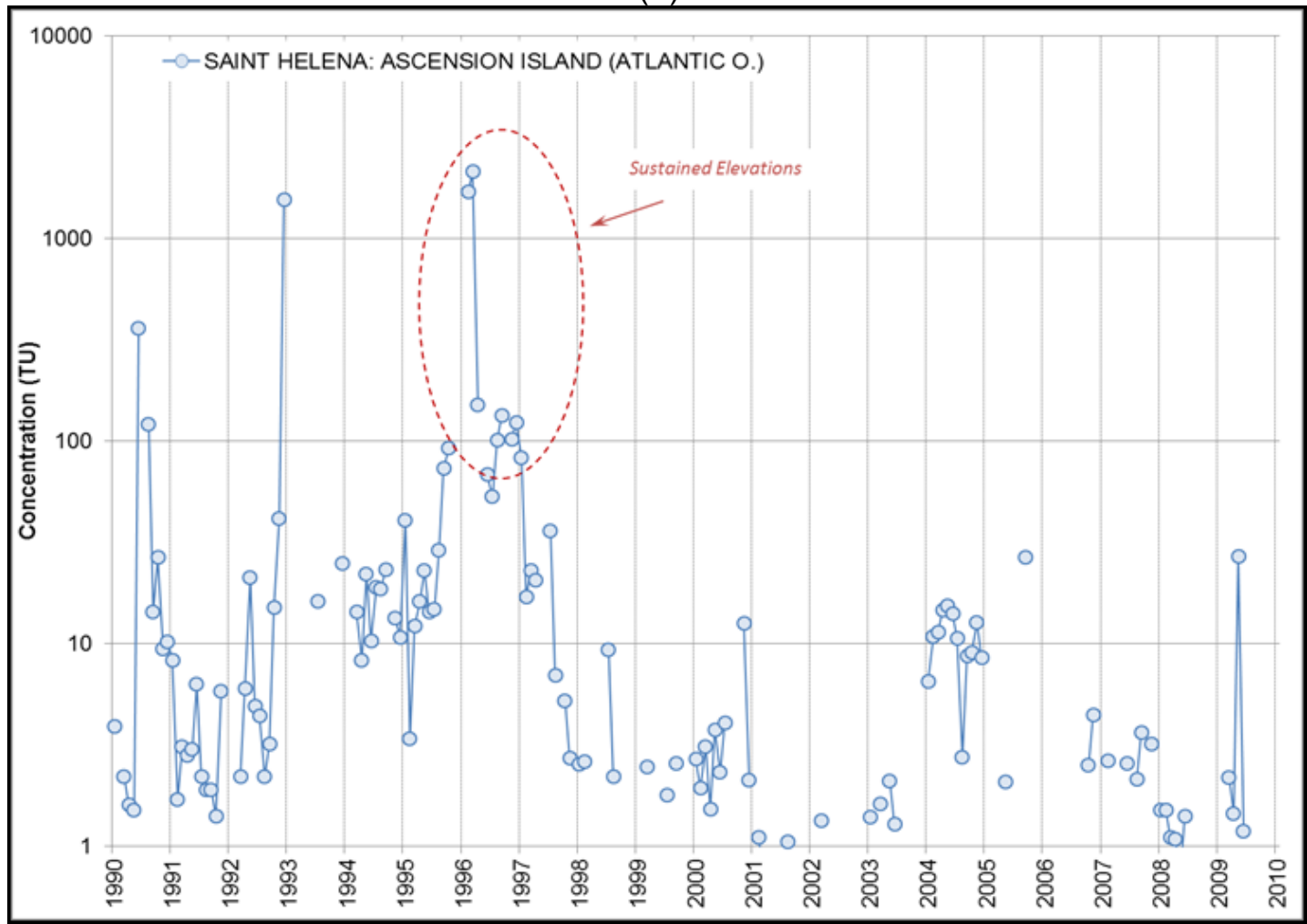

(b)

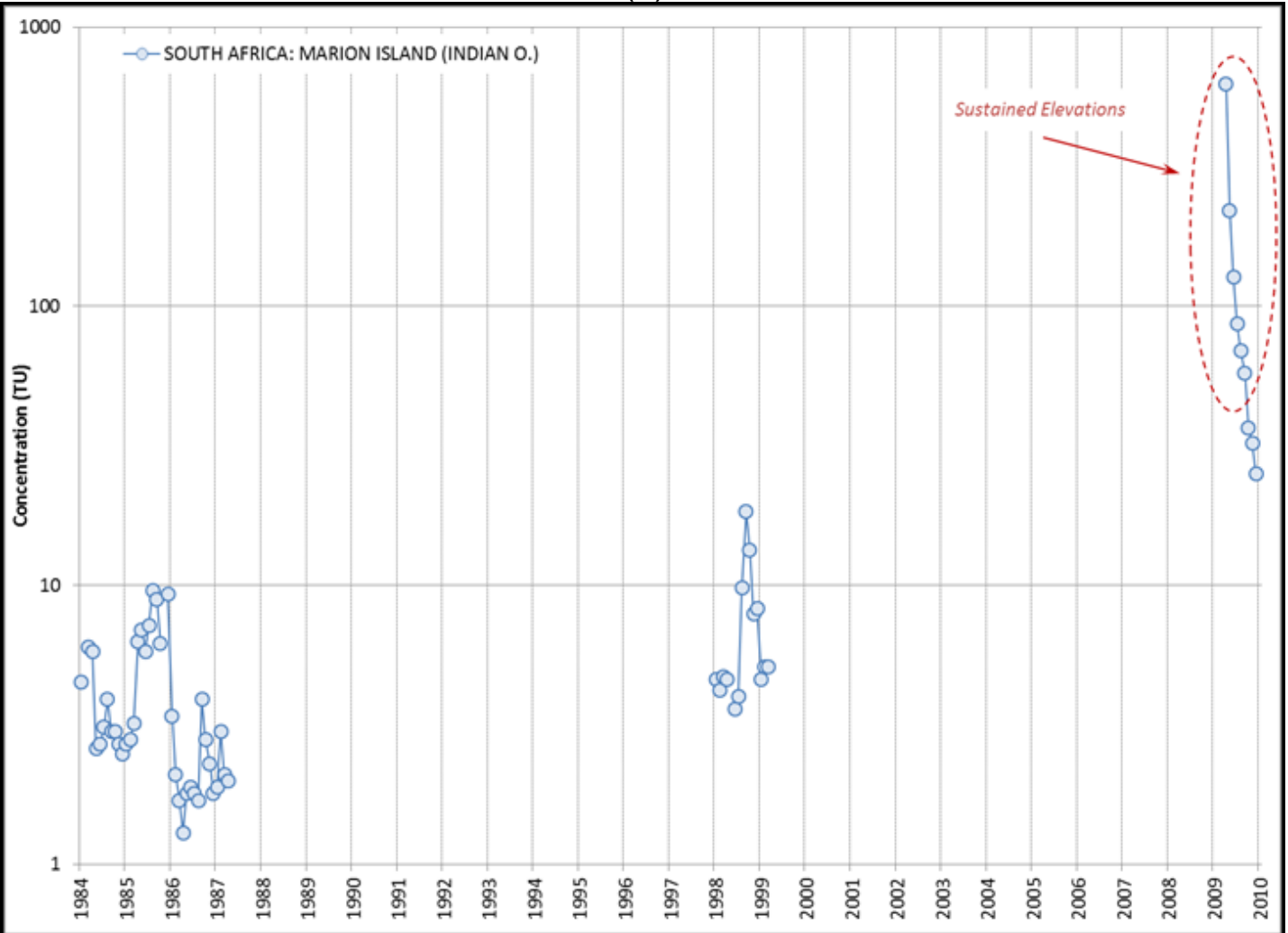

Figure 7: Time series of GNIP tritium concentrations at (a) Ascension Island (Atlantic Ocean) from 1990 to 2009, and (b) Marion Island (Indian Ocean) from 1984 to 2009. 


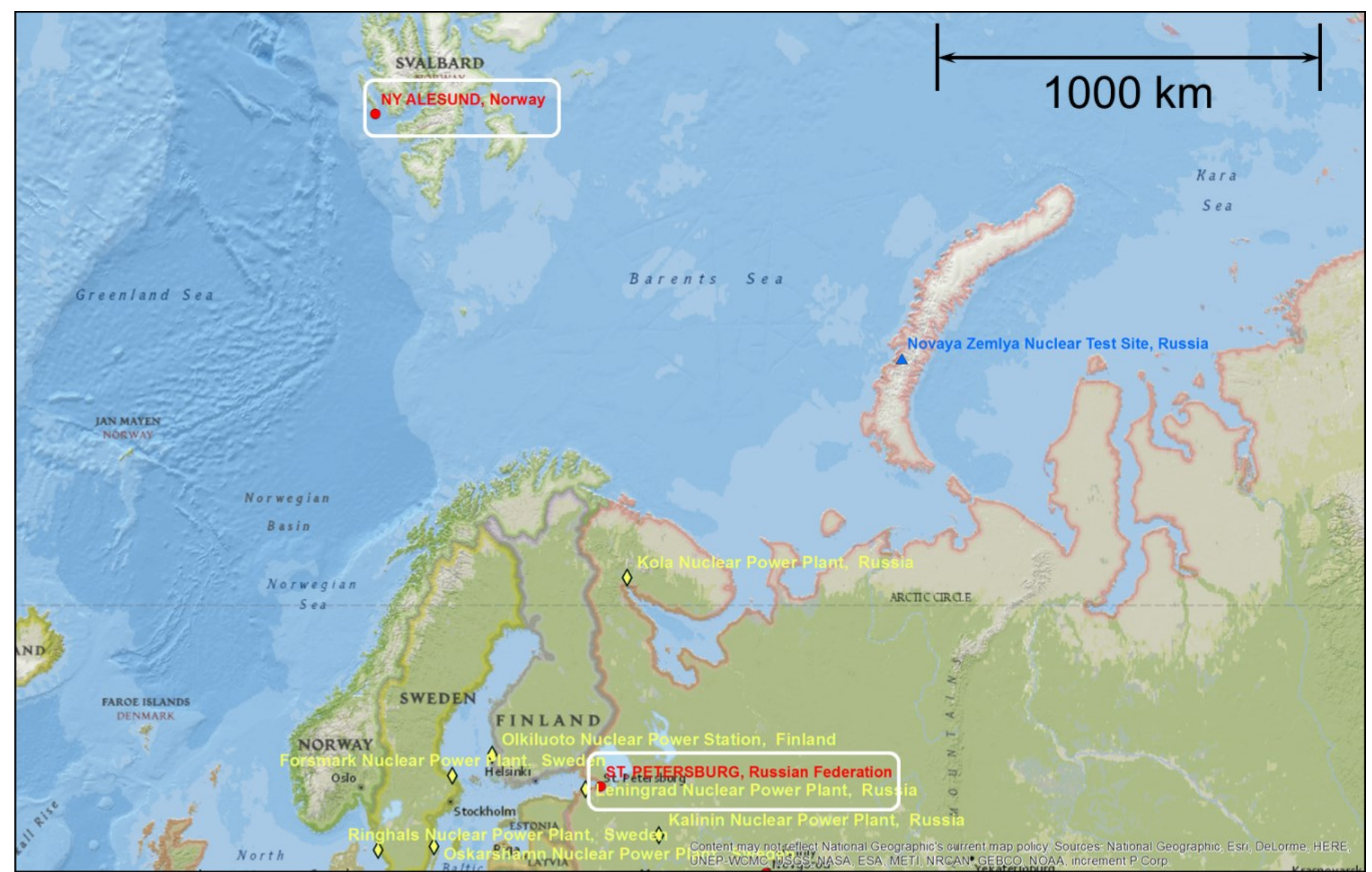

Figure 8: Map of region with GNIP sample locations of unusually high tritium concentration in Russia (St. Petersburg) and Norway (Ny Alesund). Nuclear power station sources are shown in yellow and a test site in Novaya Zemlya is indicated in blue. 


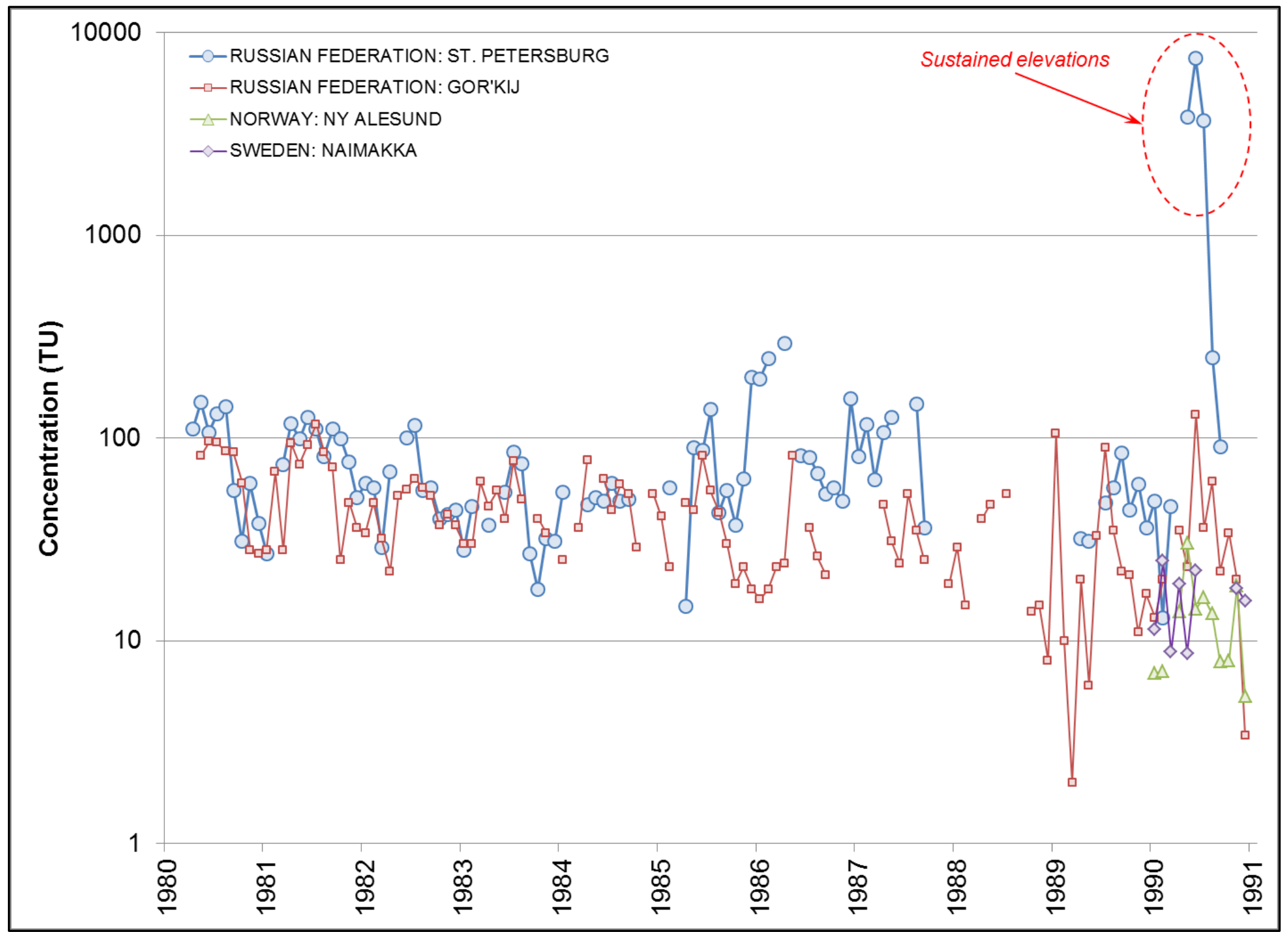

Figure 9: Time series of GNIP tritium concentrations at St. Petersburg, Russia (and available data from other stations in the region) from 1980 to 1991. 


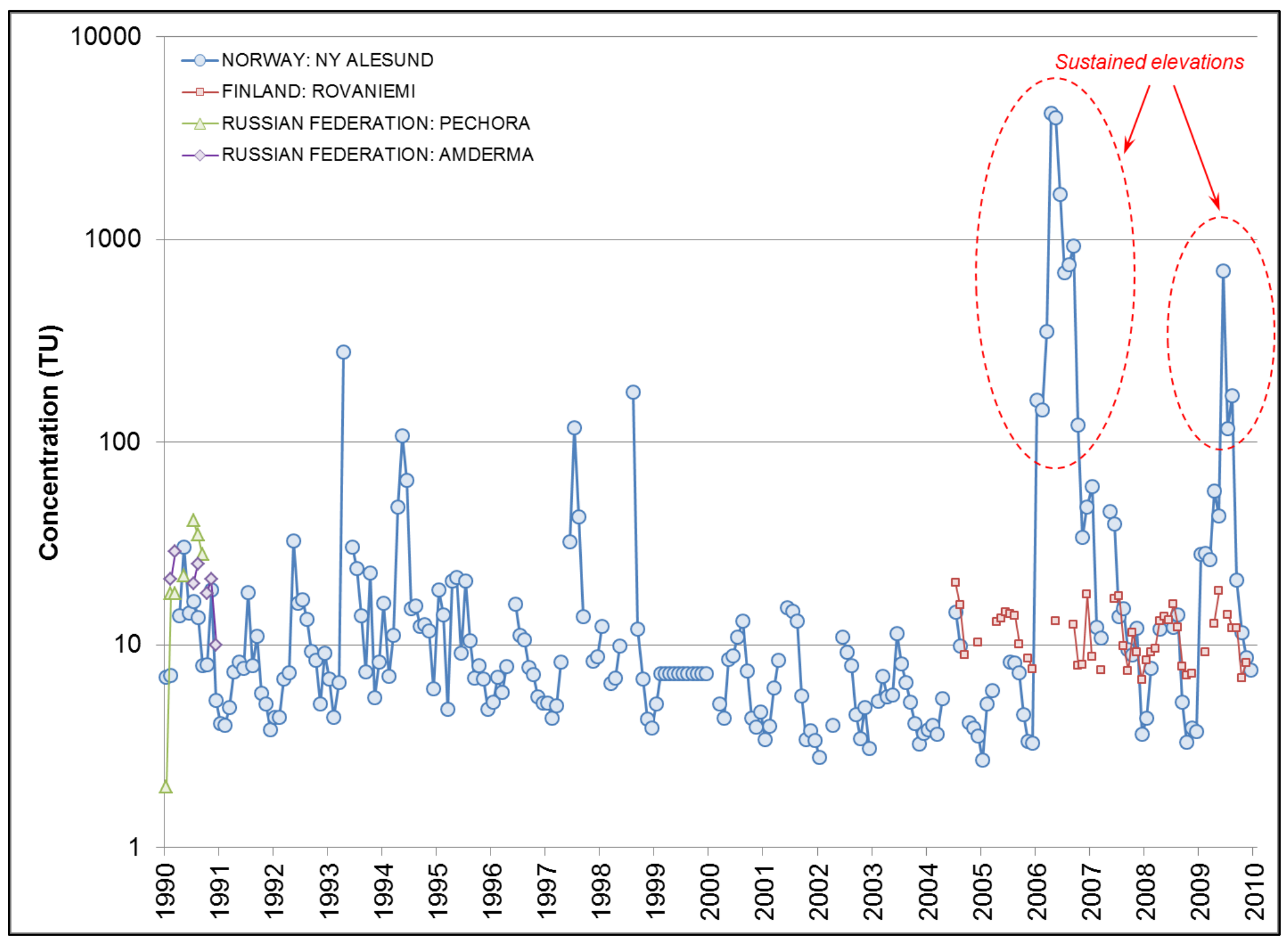

Figure 10: Time series of GNIP tritium concentrations at Ny Alesund, Norway (and available data from other stations in the region) from 1990 to 2009. 


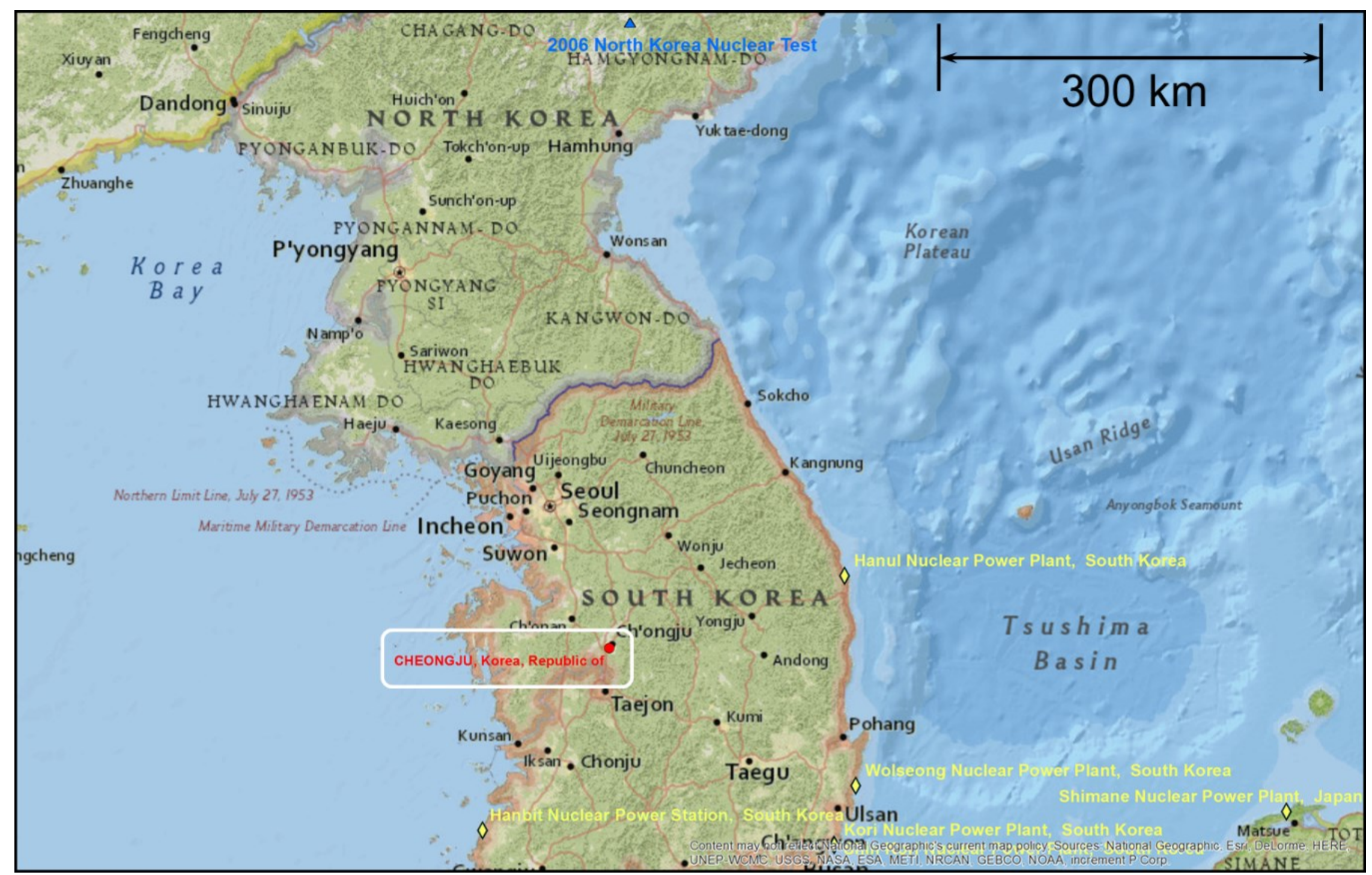

Figure 11: Map of region with GNIP sample locations of unusually high tritium concentrations in South Korea (Cheongju). Nuclear power station sources are shown in yellow and a test site in North Korea is indicated in blue. 


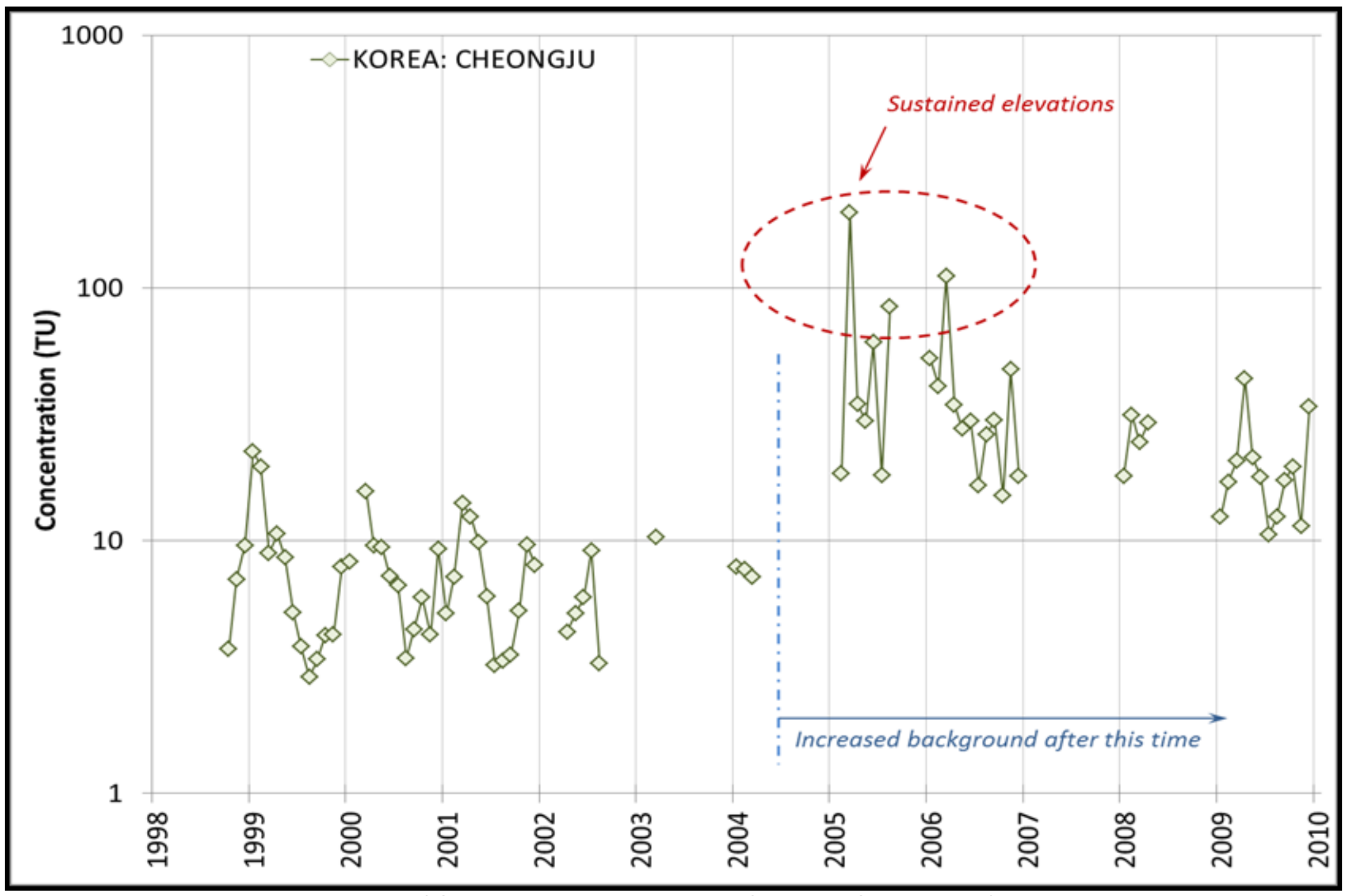

Figure 12: Time series of GNIP tritium concentrations at Cheongju, South Korea from 1998 to 2009. 


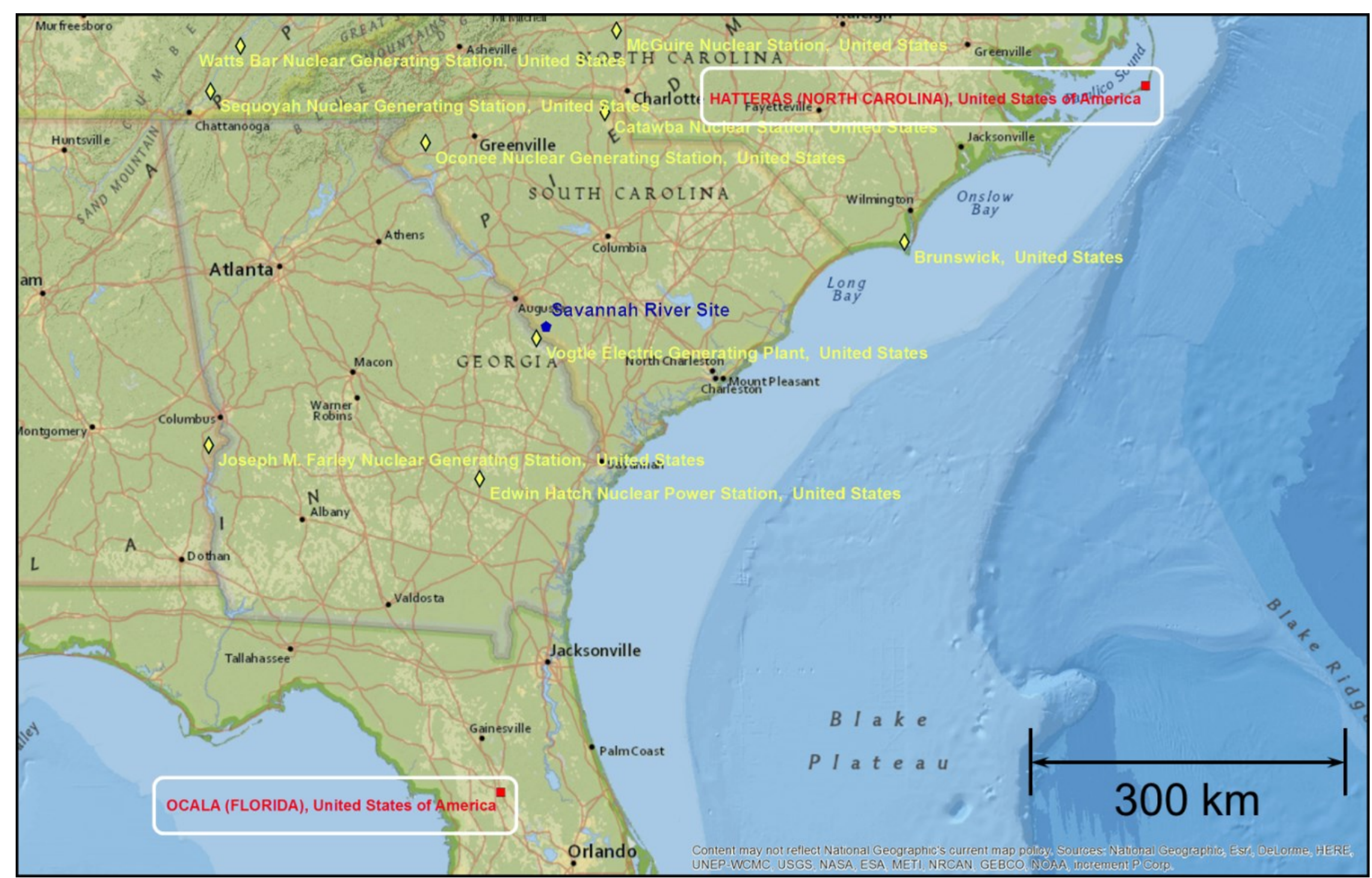

Figure 13: Map of southeastern United States with potential sources of tritium (nuclear power station in yellow, DOE Savannah River Site in blue) along with GNIP samplers (red). 


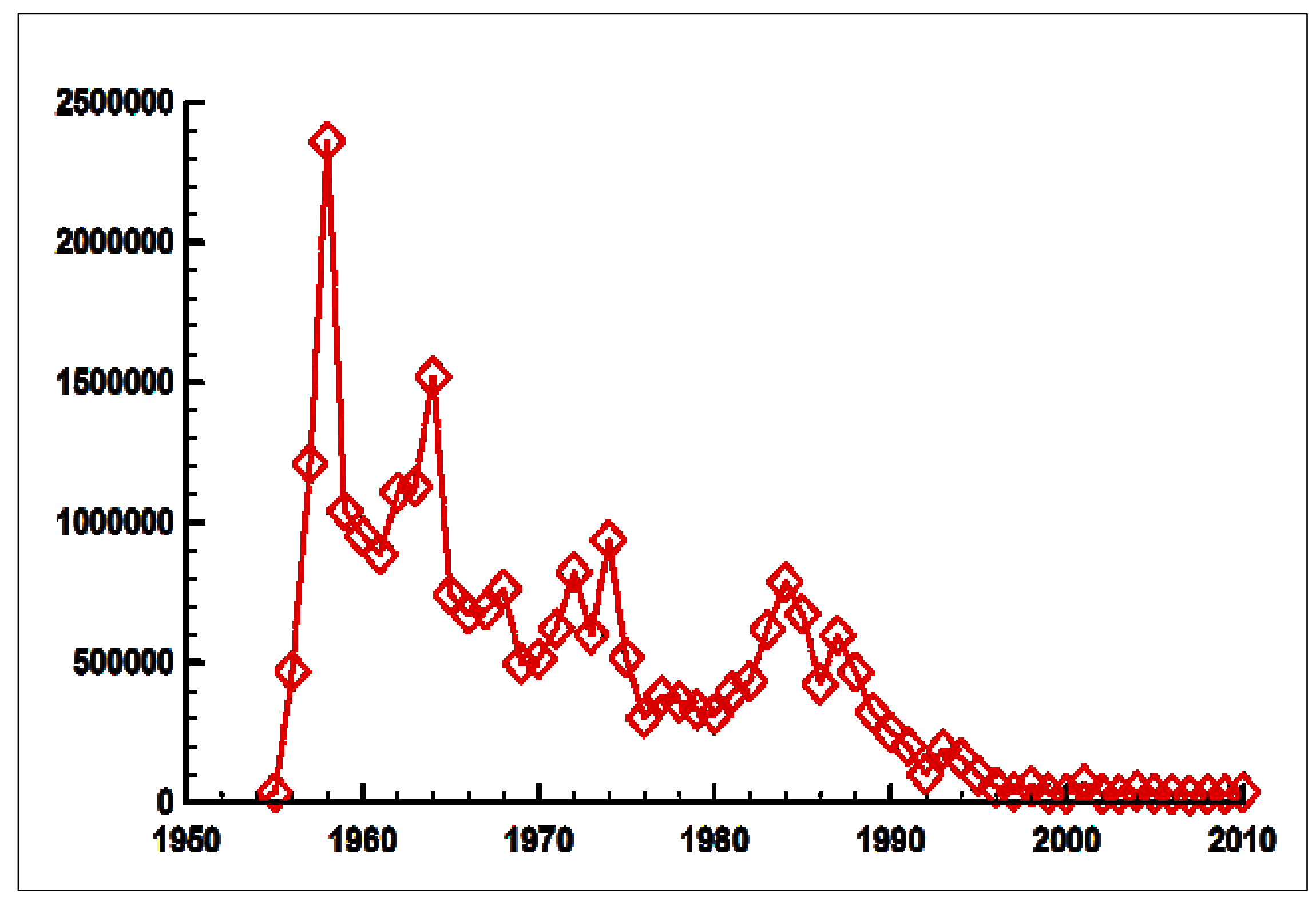

Figure 14: Annual tritium emissions (Ci) from the Savannah River Site. 
(a)

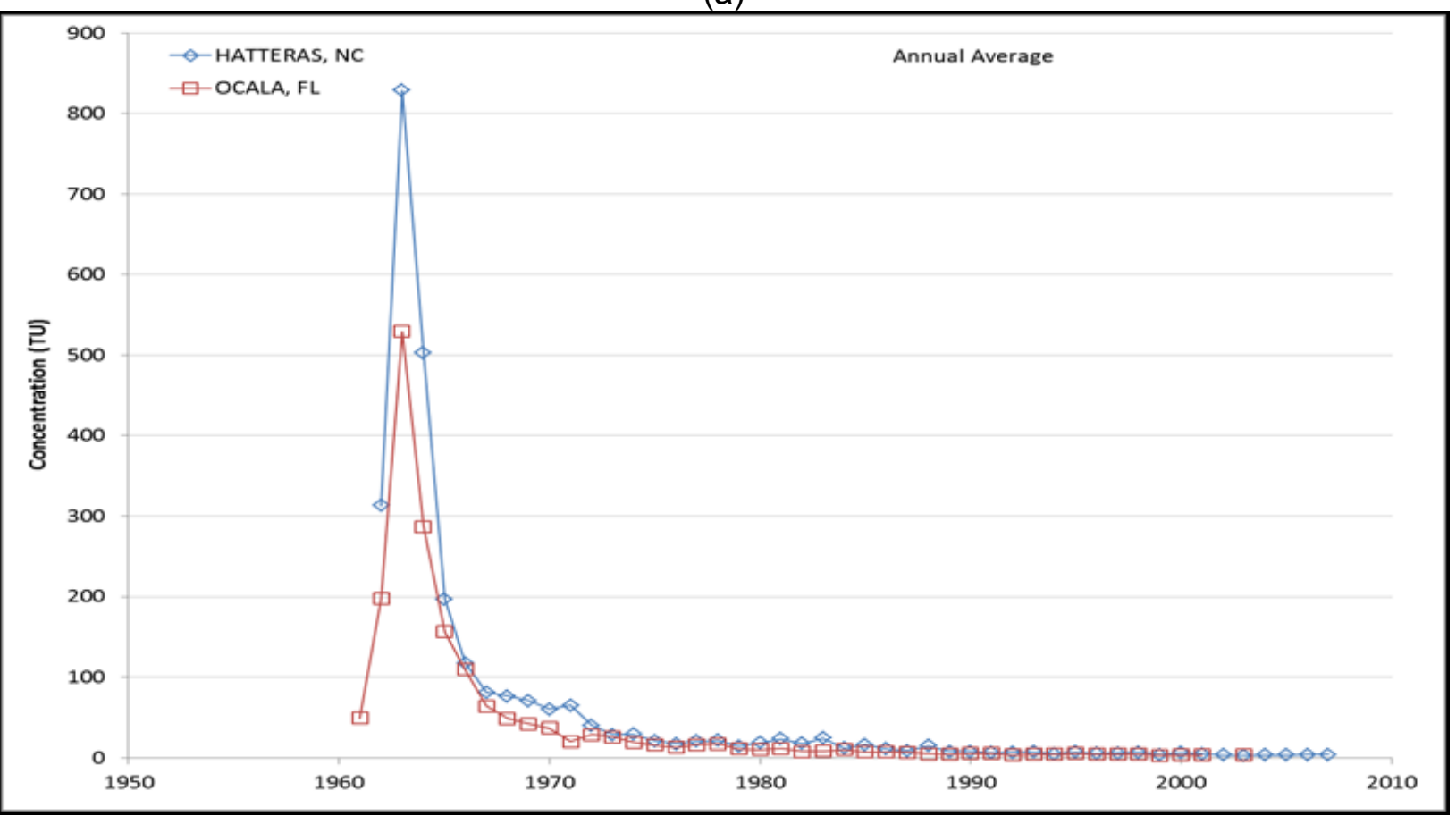

(b)

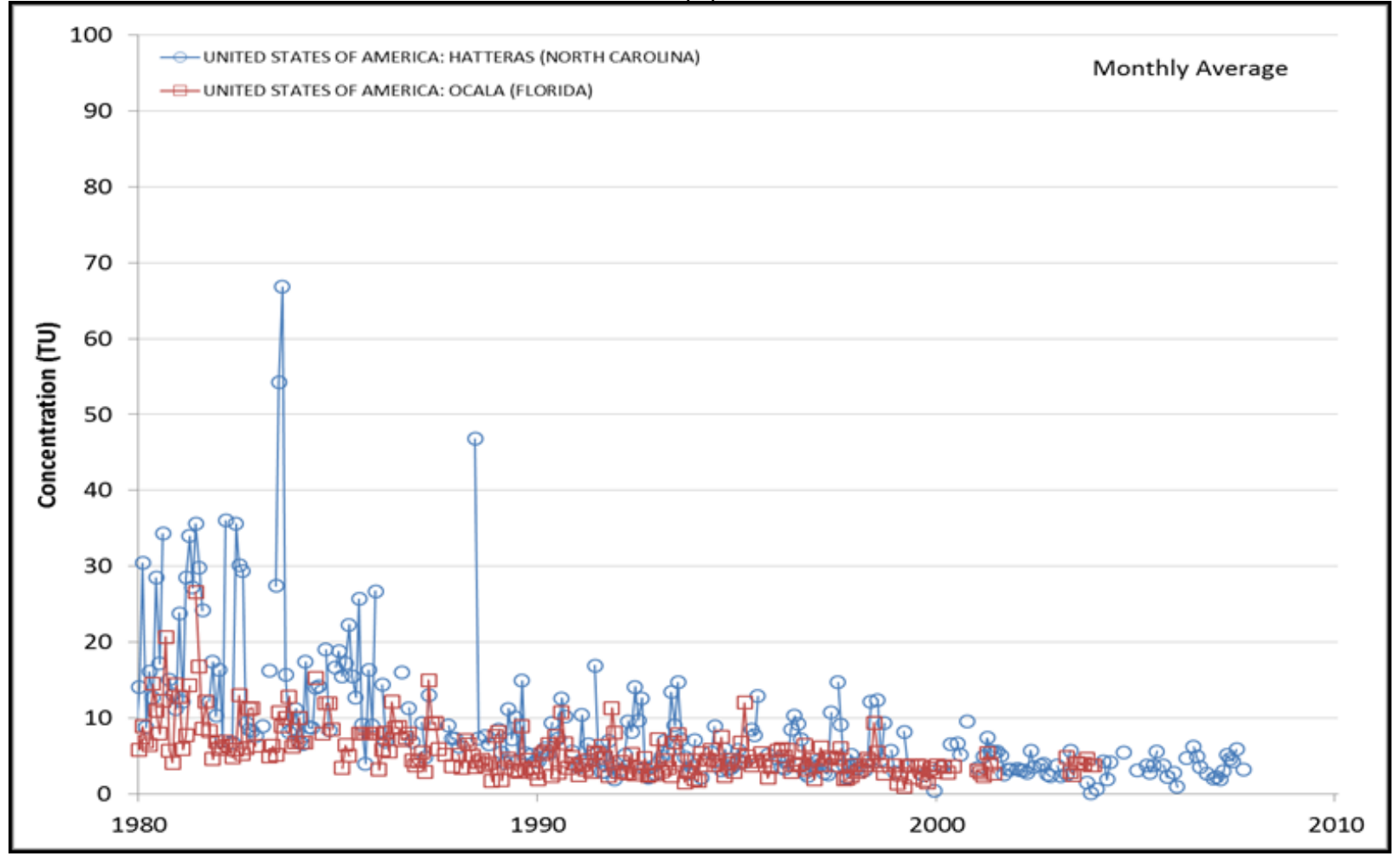

Figure 15: Time-series of GNIP tritium concentrations at Ocala, Florida and Hatteras, North Carolina. (a) Annual average from 1961 to 2007. (b) Monthly average from 1980 to 2007. 
Distribution:

L. Chandler, 773-A

S. Chiswell, 773-A

P. Cloessner, 773-A

C. Hunter, 773-A

M. Parker, 735-7A

D. Pretorius, 773-43A

R. Rabun III, 735-A

L. Tovo, 735-A

B. Viner, 773-A 